\title{
KONFLIK PEMBEBASAN LAHAN PEMBANGUNAN BENDUNGAN JATIGEDE DI DESA WADO
}

\author{
Muthi Amila dan Elly Malihah \\ Mahasiswa Program Studi Pendidikan Sosiologi FPIPS Universitas Pendidikan Indonesia \\ E-mail: muthi.amila@student.upi.edu
}

\begin{abstract}
The research talks about the conflict of the land acquisition of Jatigede dam construction at Wado, Sumedang. This research has a purpose to know how the process of a land acquisition is, the causative factors of a land acquisition, the impacts of a land acquisition and the conflict resolution for the land acquisition of Jatigede dam construction in Wado. This research usedqualitative approach and case study method. The data collected with observation technique, deep interview and documentation study. The research informant consists of the land acquisition committee, the institution in Wado,the society figure and the people who got the impact. The result of this research shows that the process of a land acquisition make horizontal conflict and vertical conflict come up which caused by the individual differences and had a impact on social system and society economic. Active participation and teamwork is the most effective effort in solving the conflict of the land acquisition of Jatigede dam construction.
\end{abstract}

Keyword : Conflict, Land Acquisition, Dam construction

\section{ABSTRAK}

Penelitian ini membahas konflik pembebasan lahan pembangunan Bendungan Jatigede di Desa Wado Kecamatan Wado Kabupaten Sumedang. Penelitian ini bertujuan untuk mengetahui bagaimana proses pembebasan lahan di Desa Wado, faktor yang melatarbelakangi konflik pembebasan lahan, dampak konflik pembebasan lahan, serta upaya penyelesaian konflik pembebasan lahan pembangunan bendungan Jatigede di Desa Wado.Penelitian ini menggunakan pendekatan kualitatif dan metode studi kasus. Pengumpulan data dilakukan dengan teknik observasi, wawancara mendalam,dan studi dokumentasi. Informan penelitian terdiri dari pihak panitia pembebasan lahan, aparat desa, tokoh masyarakat, dan masyarakat yang terkena dampak. Hasil penelitian ini menunjukkan bahwa proses pembebasan Iahan memicu terjadinya konflik horizontal dan konflik vertikal yang dilatarbelakangi oleh adanya perbedaan individu serta berdampak pada sistem sosial dan ekonomi masyarakat. Partisipasi aktif dan kerjasama 
merupakan upaya yang paling efektif dalam mengatasi konflik pembebasan lahan pembangunan Bendungan Jatigede.

Kata Kunci: konflik, pembebasan lahan, pembangunan bendungan

\section{PENDAHULUAN}

Pembangunan

merupakan perubahan yang terencana menuju suatu perbaikan.Pembangunan memiliki tujuan untuk meningkatkan kualitas seluruh aspek kehidupan masyarakat yakni aspek sosial, budaya, politik, dan ekonomi guna mewujudkan kesejahteraan sosial. Namun Namun dalam pelaksanaannya tidaklah selalu berbanding lurus dengan apa yang diharapkan, karena segala perubahan terutama pembangunan selalu disertai dengan permasalahan bahkan konflik, khususnya dalam pembangunan

Bendungan.

Pembangunan bendungan melibatkan aspek lingkungan fisik berupa sumber daya lahan serta aspek sosial berupa sistem kependudukan sehingga memerlukan sistem administrasi berupa proses pembebasan lahan. Pada proses pembebasan lahan terdapat sejumlah permasalahan ataupun pertentangan yang mendorong terjadinya konflik, tentunya konflik tersebut harus disertai dengan upaya penyelesaiannya. Adapun salah satu contoh pembangunan bendungan yang akan dibahas dalam penelitian ini adalah pembangunan Bendungan Jatigede di Desa Wado.

Bendungan Jatigede terletak di Kabupaten Sumedang, sumber air bendungan berasal dari aliran Sungai Cimanuk di wilayah Kecamatan Jatigede
Sumedang.Bendungan ini disebutsebut sebagai bendungan terbesar di Asia Tenggara.Pembangunan Bendungan Jatigede membawa implikasi penting bagi pembangunan nasional khususnya pembangunan regional Jawa Barat. Tujuan utama pembangunan bendungan Jatigede adalah untuk pengendalian banjir dan pengelolaan irigasi guna meningkatkan produktivitas di bidang pertanian, mengurangi resiko banjir di daerah hilir, serta mendorong perkembangan ekonomi berupa peningkatan pendapatan daerah melalui bidang pariwisata yang mencakup 4 kabupaten yaitu Kabupaten Sumedang, Kabupaten Indramayu, Kabupaten Cirebon, dan Kabupaten Majalengka.

Desa Wado Kecamatan Wado merupakan salah satu wilayah yang terkena dampak pembangunan Bendungan Jatigede.Pada pelaksanaan upaya pembebasan lahan di Desa Wado muncul gejolak sosial dalam masyarakat, keberagaman respond dan kesiapan masyarakat dalam menghadapi upaya pembebasan lahan mendorong terjadinya konflik. Konflik merupakan "suatu proses sosial dimana individu atau kelompok berusaha memenuhi tujuannya dengan jalan menentang pihak lawan dengan disertai ancaman dan kekerasan" Soekanto (2013, hlm. 35). Konflik-konflik tersebut diantaranya berupa aksi demonstrasi yang 
dilakukan oleh masyarakat. Bentuk aksi demonstrasi pun beragam diantaranya ada yang dengan mengajukan petisi dan surat pernyataan complain kepada pihak Desa yang kemudian disampaikan ke pihak pemerintah pusat, kemudian ada yang melakukan aksi unjuk rasa ke sejumlah kantor pemerintah pusat, dan ada pula masyarakat yang memilih bertahan tinggal di permukiman yang merupakan lokasi genangan bendungan.

Untuk mengetahui deskripsi proses pembebasan lahan serta konflik pembebasan lahan pembangunan Jatigede di Desa Wado, maka dari itulah, peneliti tertarik untuk meneliti dan mengetahui hal tersebut. Diperlukan adanya upaya analisis mengenai kondisi faktual bagaimana proses pembebasan lahan pembangunan Bendungan Jatigede, kemudian faktor-faktor apa saja yang melatar belakangi terjadinya konflik pembebasan lahan, kemudian dampak apa saja yang muncul dari adanya konflik pembebasan lahan, sehingga dapat ditemukan solusi yang tepat untuk menangani berbagai konflik pembebasan lahan serta permasalahan sosial yang dialami oleh masyarakat yang terkena dampak.

\section{METODE}

Penelitian ini merupakan penelitian kualitatif dengan menggunakan metode studi kasus. Penelitian dilakukan di Desa Wado, Dusun Buah Ngariung dan Dusun Maleber. Informan penelitian sebanyak 14 orang, terdiri atas delapan orang informan kunci, dan enam orang informan pendukung. Partisipan dalam penelitian ini mencakup panitia pembebasan lahan (Dinas Pertanahan), aparat desa, tokoh masyarakat, serta masyarakat yang terkena dampak pembangunan bendungan Jatigede. Pihak-pihak tersebut dianggap mempunyai informasi yang dibutuhkan peneliti untuk mengungkapkan permasalahan yang telah dirumuskan.Pemilihan partisipan untuk penelitian ini menggunakan purpossive sampling dan incidental sampling.Hasil penelitian yang diperoleh melalui teknik observasi, wawancara dan studi dokumentasi.

\section{HASIL DAN PEMBAHASAN}

Berdasarkan hasil penelitian, Proses pembebasan lahan terdiri dari tahapan yang sistematis, berlandaskan hukum, serta berdasarkan kesepakatan bersama. Proses pembebasan lahan dapat memicu terjadinya konflik vertikal dan horizontal. Konflik vertikal, konflik antar komponen masyarakat di dalam satu struktur yang memiliki hierarki. Konflik horizontal, konflik yang terjadi antara individu atau kelompok yang memilikikedudukan yang relatif sama (Kusnadi, 2002, hlm.67).

Konflik vertikal terjadi antara pemerintah pusat maupun pemerintah daerah dengan masyarakat yang terkena dampak, bermuara dari adanya ketidakpuasanserta ketidakadilan yang dirasakan oleh masyarakat, karena lebih banyak dampak negatif yang diterima dari adanya pembangunan bendungan Jatigede, 
sehingga hal tersebut mendorong aksi demonstrasi.Suatu bentuk kecemasan, ketidakberdayaan, keberakaran, dan keraguan yang semuanya mengarah pada permusuhan yang pada akhirnya dapat menimbulkan konflik.(Budimansyah, D., 2015)

Konflik horizontal terjadi antara sesama masyarakat yang terkena dampak dipicu oleh adanya kecemburuan sosial antar masyarakat, karena adanya perbedaan besar uang ganti rugi yang diterima.Konflik yang terjadi berupa konflik konstruktif, dimana konflik masih berada dalam batas kewajaran karena aksi yang muncul tidak sampai menyebabkan bentrokan fisik. Konflik konstruktif merupakan konflik yang bersifat fungsional, konflik ini muncul karena adanya perbedaan pendapat dari kelompok-kelompok dalam menghadapi suatu permasalahan dan akan menghasilkan suatu konsensus dari berbagai pendapat tersebut serta menghasilkan suatu perbaikan."(Robert H. Lauer, 2001, hlm. 98).

Faktor penyebab yang melatarbelakangi terjadinya konflik pembebasan lahan adalah adanya perbedaan individu dalam masyarakat, perbedaan tersebut terdiri dari perbedaan karakteristik, pendapat, pola pikir, serta kemampuan individu berupa kesiapan, keterbukaan, serta pola pikir kritis dalam menanggapi proses pembebasan lahan. Hal tersebut sejalan dengan pendapat Soekanto (2006, hlm. 91) "perbedaan antara individu-individu (karakteristik dan pola pikir), perbedaan kepribadian, serta perbedaan kepentingan akan melahirkan suatu bentrokan di antara individu yang kemudian menjadi sumber konflik." Perbedaan uang ganti rugi, perbedaan pengetahuan individu, kerusakan lingkungan, serta perpindahan ke tempat relokasi yang kurang berkembang menjadi faktor utama konflik pembebasan lahan. Hal tersebut sejalan dengan jurnal penelitian Mpogole, et.all (2011) dengan judul "The negative impact of land acquisition on indigenous communities 'livelihood andenvironment in Tanzania, Habitat International' kompensasi rendah, degradasi lingkungan, rendahnya tingkat pendidikan dan ketidaktahuan hukum menyebabkan perselisihan terjadi antara pemerintah dan masyarakat yang terkena dampak.Kemudian, Mutmainnah (1998) berpendapat bahwa penyebab konflik pembebasan lahan diantaranya ganti rugi yang tidak memadai, proses pembebasan tanah tidak demokratik dan cenderung manipulatif, penolakan petani dan pemilik tanah untuk menyerahkan tanah garapan atau tanah miliknya, ketidakpastian hidup pasca penggusuran, dan penggunaan unsur kekerasan dalam proses pembebasan tanah.Akar dari timbulnya konflik yaitu adanya hubungan sosial, ekonomi, politik yang akarnya adalah perebutan atas sumber-sumber kepemilikan, status sosial dan kekuasaan yang jumlah ketersediaanya sangat terbatas dengan pembagian yang tidak merata di masyarakat.(Setiadi \& Kolip, 2011) 
Proses pembebasan lahan pembangunan Bendungan Jatigede memberikan dampak yang mempengaruhi sistem sosial dan ekonomi masyarakat. Dampak tersebut berupa dampak positif maupun dampak negatif.Dampak positif berupa perbaikan tingkat kesejahteraan masyarakat karena adanya uang ganti rugi, dimana masyarakat dapat membangun tempat tinggal yang lebih layak dari sebelumnya serta adapula masyarakat yang menggunakan uang ganti rugi sebagai modal usaha.Hal tersebut memiliki kesamaan dengan yang diungkapkan dalam jurnal penelitian Chengri Ding (2007) dengan judul "Policy and praxis of land acquisition in China" bahwa pembebasan lahan adalah sarana utama untuk meningkatkan pertumbuhan ekonomi dan perkotaan yang pesat di Cina.

Dampak positif disertai dengan dampak negatif diantaranya berupa kerusakan lingkungan alami Desa Wado sehingga menjadi gersang, hilangnya tempat tinggal, hilangnya lahan sawah atau pertanian, hilangnya pekerjaan mendorong banyaknya pengangguran, sulitnya masyarakat untuk beradaptasi dengan lingkungan baru seperti tempat tinggal baru dan kondisi masyarakat yang baru juga, serta perpindahan ke tempat relokasi yang kurang berkembang karena belum dilengkapi sarana prasarana yang memadai. Pernyataan tersebut juga berbandinglurus dengan Jurnal penelitian Chen, et.all (2015) dengan judul "Spatiotemporal patterns of tropical deforestation and forest degradation in response to the operation of the Tucuruí hydroelectric dam in the Amazon basin" rencana pembangunan ratusan bendungan hidroelektrik di lembah amazon memiliki potensi untuk memberikan sumber daya energi berharga untuk membantu dalam mengamankan kebutuhan energi di masa depan dan pertumbuhan ekonomi yang berkelanjutan; mega-struktur, namun secara langsung dan tidak langsung mengganggu dinamika ekosistem lingkungan dan dapat menyebabkan hilangnya tumbuhan. Maka dari itu, dampak yang dirasakan oleh masyarakat berbeda-beda tergantung pada penerimaan masing-masing individu.

Upaya untuk mengatasi konflik pembebasan lahan sangat beragam, diantaranya adalah; komunikasi yang baik antara semua pihak masyarakat, penuntasan pembayaran uang ganti rugi (uang kerohiman), pertimbangan resiko pembangunan oleh pemerintah, pemberian pemahaman mengenai pengelolaan keuangan yang baik, analisis dampak sosial masyarakat dan lingkungan (penyediaan lapangan pekerjaan serta pengelolaan lingkungan yang baik), pembenahan tempat relokasi masyarakat yang terkena dampak. Sejalan dengan artikel jurnal Mpogole, et.all, 2011 yang berjudul The Negative impact of land acquisition on indigeneous communities 'livehood and environment in Tanzania' menyatakan bahwa diperlukan adanya hukum yang mengatasi masalah kompensasi, masyarakat perlu diberi pemahaman untuk hidup 
berdampingan dengan lingkungan serta penguatan program pelestarian lingkungan, kemudian akses seluruh masyarakat ke lembaga formal untuk memperoleh keadilan harus dipermudah. Hal tersebut juga dijelaskan dalam jurnal penelitian Delgado \& Romero (2016) dengan judul "Environmental Modelling \& Software Environmental con $\mathrm{fl}$ ict analysis using an integrated grey clustering and entropy-weight method : A case study of a mining project in Peru" bahwa analisis konflik lingkungan telah menjadi faktor kunci untuk validitas proyek dan kesejahteraan penduduk yang terkena dampak. Pengelolaan lingkungan yang baik terutama di lingkungan baru dapat membantu dalam mengatasi konflik.Diperlukan adanyakerjasama seluruh masyarakat dalam memelihara serta menjaga lingkungan baru agar tetap asri.Sebagai tambahan, dibutuhkan adanya suatu pendidikan berbasis masyarakat untuk mengatasi permasalahan lingkungan.Pendidikan berbasis masyarakat untuk mengembangkan karakter kesadaran lingkungan didasarkan pada nilai-nilai masyarakat (reuse, reduce, recycle) yang diimplementasikan pada pembelajaran yang terinternalisasi ke dalam masing-masing individu, budaya tidak hanya berperan dalam aspek formal juga memainkan peran dalam aspek informal yang mempengaruhi pikiran, perasaan, dan perilaku sehari-hari individu. (Samong, F., Suryadi, A., \& Budimansyah, D., 2015)

Berbagai upaya untuk mengatasi konflik pembebasan lahan dapat efektif dilaksanakan jika seluruh komponen dan lapisan masyarakat saling bekerjasama dalam berbagai upaya penyelesaian konflik.Dibutuhkan adanya partisipasi aktif dari seluruh masyarakat serta pola pikir kritis masyarakat untuk dapat menemukan jalan keluar bagi konflik pembebasan lahan.

\section{SIMPULAN}

Proses pembebasan lahan pembangunan Bendungan Jatigede menimbulkan konflik vertikal dan konflik horizontal yang melibatkan pemerintah dan masyarakat Desa Wado yang terkena dampak. Konflik yang muncul berupa aksi demonstrasi, dalam bentuk pengajuan petisi atau complain yang diajukan ke pihak desa kemudian disampaikan kembali kepada pihak pemerintah pusat serta, adapula masyarakat yang memilih tetap tinggal dilokasi genangan hingga pembayaran uang ganti rugi diselesaikan.

Konflik tersebut dilatarbelakangi oleh ketidakpuasan serta ketidakadilan yang dirasakan oleh masyarakat, karena lebih banyak dampak negatif yang diterima dari adanya pembangunan bendungan Jatigede, kecemburuan sosial antar masyarakatkarena adanya perbedaan besar uang ganti rugi yang diterima, serta perbedaan individu berupa; karakteristik, pendapat, pola pikir, dalam menanggapi proses pembebasan lahan.

Dampak konflik pembebasan lahan yang diterima oleh masyarakat Desa Wado berupa dampakpositif 
dan dampak negatif.Dampak positifyakni peningkatan kesejahteraan masyarakat karena adanya uang ganti rugi yang diterima masyarakat yang dapat digunakan untuk membangun tempat tinggal yang lebih layak ataupun digunakan untuk modal usaha. Sedangkan, dampak negatif yaitu kerusakan lingkungan alami, hilangnya tempat tinggal, hilangnya lahan sawah atau pertanian, hilangnya pekerjaan mendorong banyaknya pengangguran, sulitnya masyarakat untuk beradaptasi dengan lingkungan baru (tempat tinggal baru dan kondisi masyarakat yang baru), serta perpindahan ke tempat relokasi yang kurang berkembang karena belum dilengkapi sarana prasarana yang memadai.

Upaya untuk mengatasi konflik pembebasan lahan di Desa Wado pun sangat beragam, diantaranya adalah; komunikasi yang baik antara semua pihak masyarakat (negosiasi), penuntasan pembayaran uang ganti rugi (uang kerohiman), pertimbangan resiko pembangunan oleh pemerintah, pemberian pemahaman mengenai pengelolaan keuangan yang baik, analisis dampak sosial masyarakat dan lingkungan (penyediaan lapangan pekerjaan dan pengelolaan lingkungan yang baik), serta pembenahan tempat relokasi masyarakat yang terkena dampak.Partisipasi aktif dan kerjasama menjadi upaya yang paling efektif dalam mengatasi konflik pembebasan lahan pembangunan Bendungan Jatigede di Desa Wado.
Buku:

H. Lauer, Robert. (2001). Perspektif Tentang Perubahan Sosial.Jakarta : PT. Rineka Cipta.

Kusnadi.(2002). Masalah Kerja Sama, Konflik dan Kinerja.Malang : Taroda.

Mutmainnah.(1998). Jembatan Suramadu. Yogyakarta: LKPSM Setiadi, E.M. \& dan Kolip, U. (2011). Pengantar Sosiologi Pemahaman Fakta dan Gejala Permasalahan Sosial: Teori, Aplikasi dan Pemecahannya. Jakarta: Kencana

Soekanto, Soerjono (2006) Sosiologi Suatu Pengantar. Jakarta : Raja Grafindo Persada

Soekanto, Soerjono. (2013). Sosiologi Suatu Pengantar. Jakarta: Rajawali Pers

\section{Jurnal}

$\tilde{A}, C$. D. "Policy and praxis of land acquisition in China." Land Use Policy, 24. (2007): 1-13.

Chen, G., Powers, R. P., Carvalho, L. M. T. De, \& Mora, B. "Spatiotemporal patterns of tropical deforestation and forest degradation in response to the operation of the Tucuruí hydroelectric dam in the Amazon basin."Applied Geography, 63, (2015): 1-8.

Delgado, A., \& Romero, I. "Environmental Modelling \& Software Environmental con $\mathrm{fl}$ ict analysis using an integrated grey clustering and entropyweight method: A case study of a mining project in Peru."Environmental Modelling 
and Software, 77. (2016): 108121.

Budimansyah, D. "Fundamental Sociological Symptoms as a Source Occurance of Turbulence in Indonesian Society During The PostReform."1st UPI International Conference on Sociology Education, (2015): hlm. 63-66.

Mpogole, M., Kongela, S., Ayoub, M., Karimuribo, E. D., \& Kusiluka, L. J. M. "The negative impact of land acquisition on indigenous communities ' livelihood and environment in Tanzania."Habitat International, 35(1). (2011): 66-73.

Samong, F., Suryadi, A., \& Budimansyah, D. "The Development of Character Education in Primary Schools Through the Enhancement of School Culture." 1st UPI International Conference on Sociology Education,(2015): hlm. 77-79. 